\title{
Simplified Vegetative Cell Cycle of Rhodomicrobium vannielii
}

\author{
By CRAWFORD S. DOW* AND ANDREW D. FRANCE \\ Department of Biological Sciences, University of Warwick, Coventry CV4 $7 A L$
}

(Received 7 September 1979)

\begin{abstract}
Homogeneous swarm cell populations of Rhodomicrobium vannielii, selected from the lateexponential phase of growth, when cultured photoheterotrophically on solid medium yield two distinct colony types. These reflect two vegetative cell cycle expressions, one composed of the characteristic multicellular complexes, the other of a 'simplified' cell cycle composed of prosthecate, reproductive cells and motile swarm cells. This simplified cell cycle has been characterized and its derivation is discussed. The implication of the $\mathrm{CO}_{2}$ concentration as a factor in the control of expression of this cell cycle is also considered.
\end{abstract}

\section{INTRODUCTION}

Rhodomicrobium vannielii, a prosthecate 'budding' bacterium of the Rhodospirillaceae, was isolated by Duchow \& Douglas (1949) and characterized as ovoid cells (2 to $3 \times 1 \mu \mathrm{m}$ ) linked by cellular filaments or prosthecae $(0.3 \times 2$ to $30 \mu \mathrm{m})$ (Staley, 1968) which may be branched giving rise to complex multicellular arrays (Murray \& Douglas, 1950). Subsequently, motile cells were observed (Douglas \& Wolfe, 1959) and, more recently, angular heat-resistant exospores (Gorlenko, 1969). The growth, formation and reproduction of each of the cell types expressed by $R$. vannielii has been documented by Whittenbury \& Dow (1977).

Cell growth in $R$. vannielii is by obligate asymmetric polar growth ('budding'). Daughter cell formation follows filament synthesis and, on completion, cell division is by the formation of a plug within the filament. The cells remain physically attached, ultimately generating the characteristic multicellular arrays. The peritrichously flagellated swarm cells produced during the exponential phase of growth are formed sequentially from the filament tips of the multicellular complexes, cell division in this instance being by binary fission. There are therefore two modes of cell separation expressed by $R$. vannielii - binary fission, and the formation of unique and characteristic plugs within the filaments.

We describe here a 'simplified' vegetative cell cycle in which the formation of multicellular complexes is excluded, cell separation being exclusively by binary fission. The derivation and control of expression of this simplified cell cycle is discussed.

\section{METHODS}

Organism and growth conditions. Rhodomicrobium vannielii, strain $\mathrm{Rm} 5$, was from the culture collection at the Department of Biological Sciences, University of Warwick. It was grown in medium containing $\left(\mathrm{g}^{-1}\right)$ : sodium pyruvate, 1.5; sodium hydrogen malate, $1.5 ; \mathrm{NH}_{4} \mathrm{Cl}, 0.5 ; \mathrm{MgSO}_{4} .7 \mathrm{H}_{2} \mathrm{O}, 0.4 ; \mathrm{NaCl}, 0.4 ; \mathrm{CaCl}_{2}$, 0.05 . The $\mathrm{pH}$ was adjusted to $6 \cdot 8$ with $\mathrm{KOH}$ prior to autoclaving, and $50 \mathrm{ml} 0 \cdot 1 \mathrm{M}-\mathrm{NaH}_{2} \mathrm{PO}_{4} / \mathrm{Na}_{2} \mathrm{HPO}_{4}$ buffer, pH 6.8, was added aseptically after autoclaving. Medium (100 ml) was held in $250 \mathrm{ml}$ Quickfit conical flasks (B19/26) fitted with Suba-seals (W. Freeman \& Co., Barnsley, Yorks.). Flasks were gassed with $\mathrm{O}_{2}-$ free $\mathrm{N}_{2}$ and incubated with shaking at $30^{\circ} \mathrm{C}$ with incident light intensities (tungsten lamps) ranging from 1000 to $3000 \mathrm{~lx}$. 
Large-scale batch photcheterotrophic cultures of $R$. vannielii were grown in a 151 batch fermenter (L.H. Engineering Co., Stoke Poges, Bucks.) at $30^{\circ} \mathrm{C}$ with an incident light intensity of $6000 \mathrm{~lx}$.

Agar plates [formed by adding agar at $1.5 \%(\mathrm{w} / \mathrm{v})$ to the above medium] were sealed in autoclavable nylon bags (Portex, Hythe, Kent) using a Calor 'Easyseal' unit and gassed with $\mathrm{O}_{2}$-free $\mathrm{N}_{2}$ via syringe needles. Residual $\mathrm{O}_{2}$ was removed by including in the bag $25 \mathrm{ml}$ saturated pyrogallol to which was added $25 \mathrm{ml}$ alkali $\left[15 \%(\mathrm{w} / \mathrm{v}) \mathrm{K}_{2} \mathrm{CO}_{3}\right.$ plus $\left.10 \%(\mathrm{w} / \mathrm{v}) \mathrm{NaOH}\right]$ after gassing. Incubation was at $30{ }^{\circ} \mathrm{C}$ with an incident light intensity of $1500 \mathrm{~lx}$ from tungsten lamps.

Slide cultures. Agar medium was boiled for 15 min under a continuous flow of $\mathrm{O}_{2}-$ free $\mathrm{N}_{2}$, and the $\mathrm{NaH}_{2}$ $\mathrm{PO}_{4} / \mathrm{Na}_{2} \mathrm{HPO}_{4}$ buffer was added aseptically when the medium had cooled below $65^{\circ} \mathrm{C}$. Two drops of this medium (about $0.2 \mathrm{ml}$ ) were placed on a sterile microscope slide in a sandwich box which was continuously gassed with $\mathrm{O}_{2}$-free $\mathrm{N}_{2}$. A sterile coverslip was applied to produce a thin flat film of agar. After 5 to $10 \mathrm{~min}$ the cover slip was removed and the agar was inoculated with $5 \mu \mathrm{l}$ of a suspension of exponentially growing cells. A fresh sterile coverslip was placed on the agar and sealed on to the slide using a petroleum jelly/ paraffin wax mixture. Slide cultures were incubated at $30^{\circ} \mathrm{C}$ on the microscope stage with an incident light intensity of $1500 \mathrm{~lx}$ from a tungsten lamp.

Swarm cell selection. Homogeneous populations of swarm cells were obtained by the glass-wool column technique of Whittenbury \& Dow (1977).

Light microscopy. All light microscopy was carried out using Olympus EHT phase contrast microscopes fitted with Olympus PM6 camera units (Olympus Optical Co., Tokyo, Japan). Photomicrographs were taken on Kodak Panatomic X film.

Electron microscopy. Gold/palladium was used for all metal shadowing (angles $15^{\circ}$ to $45^{\circ}$ ). The fixation procedure of Ryter \& Kellenberger (1958) was followed for ultrathin sections. These were post-stained for $20 \mathrm{~min}$ in $0.5 \%$ (w/v) uranyl acetate followed by $5 \mathrm{~min}$ in $0.1 \%(\mathrm{w} / \mathrm{v})$ lead citrate in $0.1 \mathrm{M}-\mathrm{NaOH}$. All preparations were observed using an AEI Corinth 275 electron microscope.

Measurement of $\mathrm{N}_{2}, \mathrm{O}_{2}$ and $\mathrm{CO}_{2}$. Dissolved $\mathrm{N}_{2}, \mathrm{O}_{2}$ and $\mathrm{CO}_{2}$ were measured by the method described by Phillips \& Johnson (1961). Gas analysis was performed after the method of Herbert \& Holding (1972) using a gas chromatograph fitted with a katharometer detector head.

Measurement of $\mathrm{CO}_{2}$ assimilation by intact organisms. Cells were harvested by centrifugation, washed once and resuspended in complete growth medium, gassed with $\mathrm{O}_{2}$-free $\mathrm{N}_{2}$ and incubated at $30^{\circ} \mathrm{C}$ with an incident light intensity of 2000 lx from tungsten lamps. $\mathrm{NaHCO}_{3}$, to give $5 \mathrm{~mm}$, was then added followed after $10 \mathrm{~min}$ by sterile $\mathrm{NaH}^{14} \mathrm{CO}_{3}\left[1 \mu \mathrm{Ci} \mathrm{ml} l^{-1}\right.$, sp.act. $\left.656 \mu \mathrm{Ci} \mathrm{mg}^{-1}\left(24 \cdot 3 \mathrm{MBq} \mathrm{mg}^{-1}\right)\right]$. At intervals, $1 \mathrm{ml}$ samples were removed, mixed with $5 \mathrm{ml} \mathrm{cold} 5 \%(\mathrm{w} / \mathrm{v})$ trichloroacetic acid and filtered through Whatman GF/C glass filters. The filters were washed twice with $10 \mathrm{ml}$ cold $5 \%(\mathrm{w} / \mathrm{v})$ trichloroacetic acid, dried overnight at $60^{\circ} \mathrm{C}$ and then counted by immersion in scintillation fluid [ $36 \mathrm{~g}$ 2,5-diphenyloxazole and $0.45 \mathrm{~g} \mathrm{1,4-bis-(5-pheny]-}$ oxazol-2-yl)benzene in 61 toluene plus 31 Triton X-100] using a liquid scintillation spectrometer.

Dry weight estimations. Culture dry weights were measured by filtering suitable volumes through preweighed $0.4 \mu \mathrm{m}$ membrane filters (Oxoid). These were then dried at $60^{\circ} \mathrm{C}$ and allowed to cool in a desiccator before weighing. On average, 20 to $30 \mathrm{mg}$ dry weight of cells were filtered.

\section{RESULTS AND DISCUSSION}

Swarm cell production by $R$. vannielii occurred throughout the exponential phase of growth (Fig. 1). However, as the culture entered the late-exponential to early-stationary phase of growth, the number of swarm cells present reached a steady value, there being no apparent further increase in cell numbers. When homogeneous swarm cell populations selected from this part of the growth cycle (Whittenbury \& Dow, 1977) were cultured photoheterotrophically on solid medium, they gave two colony types (Fig. $2 a$ ). The first, a rough irregular colony (R), was by far the most common and was composed of multicellular arrays, i.e. the characteristic vegetative cell expression of $R$. vannielii (Fig. $2 b$ ). The second, a soft mucoid regular colony (S), was composed of single motile cells (swarm or daughter cells), single cells possessing prosthecae (mother cells) and prosthecate cells with daughter cells forming at the prostheca tip (Fig. 2c); there were no multicellular arrays. The latter colony type occurred with a frequency of 1 to $2 \%$ and constitutes a simplified vegetative cell cycle expression of $R$. vannielii. 

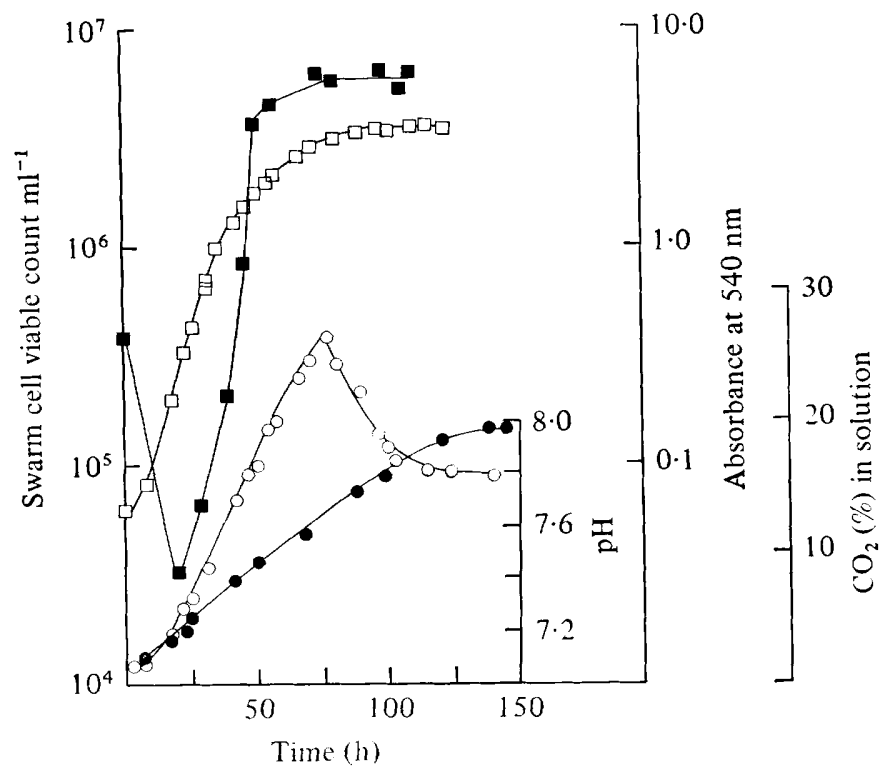

Fig. 1. Growth curve of $R$. vannielii $(\mathrm{Rm} 5)$ grown photoheterotrophically at $30{ }^{\circ} \mathrm{C}$ with an incident light intensity of $2500 \mathrm{~lx}$. Culture absorbance at $540 \mathrm{~nm}(\square)$; swarm cell viable count $\mathrm{ml}^{-1}(\square)$; culture $\mathrm{pH}(\mathrm{O})$; percentage of $\mathrm{CO}_{2}$ in solution $(\mathrm{O})\left[\mathrm{CO}_{2}, \mathrm{O}_{2}\right.$ and $\mathrm{N}_{2}$ tensions were measured in solution by the method of Phillips \& Johnson (1961) and the $\mathrm{CO}_{2}$ tension was expressed as a percentage of the total $\mathrm{CO}_{2}$ plus $\mathrm{O}_{2}$ plus $\mathrm{N}_{2}$ ].
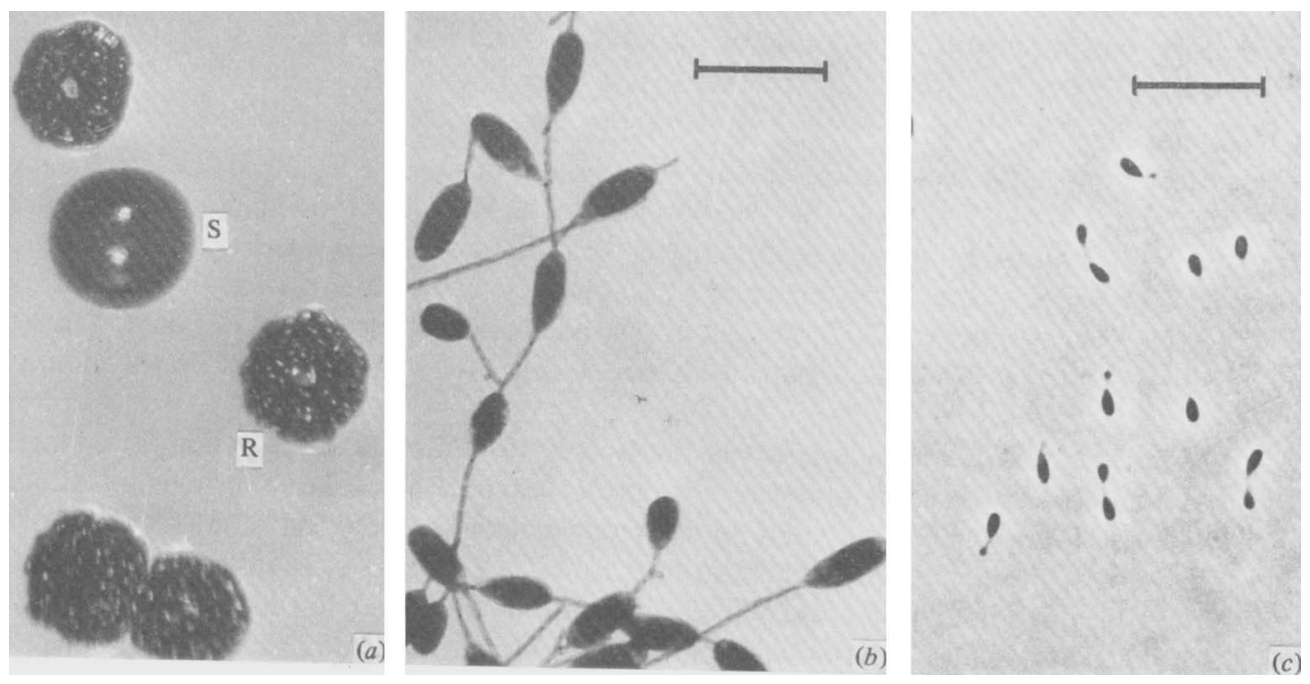

Fig. 2. (a) Colony types expressed by $R$. vannielii $(\mathrm{Rm} 5)$ grown photoheterotrophically on agar plates: $R$, rough irregular colonies which are difficult to disrupt; $S$, smooth mucoid colonies which are easily disrupted. (b) Electron micrograph (gold/palladium shadowed) of a $R$. vannielii multicellular array; bar marker represents $2.5 \mu \mathrm{m}$. (c) Phase contrast photomicrograph of $R$. vannielii cells expressing the simplified cell cycle; bar marker represents $10 \mu \mathrm{m}$. 


\section{Simplified vegetative cell cycle}

Slide culture (Fig. 3) and electron microscopic studies (Fig. 4) revealed that cell growth and reproduction in this cell cycle resembles that of Hyphomicrobium (Leifson, 1964; Hirsch, 1974; Harder \& Attwood, 1978), Rhodopseudomonas palustris and Rhodopseudomonas viridis (Whittenbury \& McLee, 1967). The immature swarm cell undergoes a period of obligate differentiation, which includes flagella shedding and synthesis of a prostheca, to become a mature reproductive mother cell. Daughter cell formation is by 'budding' or, more specifically, by asymmetric polar growth from the prostheca tip. On completion of daughter cell synthesis, cell division is by binary fission and yields a prosthecate mother cell and a motile, immature daughter cell. The mother cell can undertake the formation of a second daughter cell immediately after synthesis of a short segment of prostheca (prostheca are only ever formed at one pole). The daughter cell, however, goes through the differentiation sequence described above. The consequences of asymmetric polar growth and of a dimorphic cell cycle have been discussed by Whittenbury \& Dow (1977).

The developmental sequence from swarm cell to mature reproductive mother cell is indistinguishable from the development of swarm cells selected from a culture grown as multicellular arrays (Whittenbury \& Dow, 1977), the only exceptions being (i) growth is always from one pole whereas with swarm cells derived from multicellular arrays prosthecae may be formed from both poles and (ii) division is by binary fission and not by plug formation in the prostheca.

\section{Ultrastructure}

Cells of the simplified cell cycle possessed the characteristic lamellae membrane system of R. vannielii (Conti \& Hirsch, 1965; Whittenbury \& Dow, 1977) and of Rhodopseudomonas palustris (Whittenbury \& McLee, 1967; Dow et al., 1976). Their responses to high and low light intensities were similar, i.e. high light intensity, low content of photosynthetic membrane; low light intensity, high content of photosynthetic membrane.

\section{Growth}

When grown in liquid medium under an atmosphere of $\mathrm{O}_{2}$-free $\mathrm{N}_{2}$ at $30^{\circ} \mathrm{C}$ with an incident light intensity of $2000 \mathrm{~lx}$, the doubling time of cells composing the multicellular arrays was $5.3 \mathrm{~h}$ and that of cells expressing the simplified cell cycle was $5.0 \mathrm{~h}$. The addition of $5 \%(\mathrm{v} / \mathrm{v}) \mathrm{CO}_{2}$ to the atmosphere increased the growth rate, giving doubling times of 5.0 and $4.7 \mathrm{~h}$, respectively. There was no significant difference in ${ }^{14} \mathrm{CO}_{2}$ incorporation into cellular material by cells constituting either cell cycle when grown under identical conditions.

The only consistent differences between the two cycles relate to the $\mathrm{pH}$ changes apparent during batch growth (Fig. 5) and the amount of carbon assimilated into cell material (Fig. 6), the simplified cell cycle yielding a greater cell mass per gram of substrate carbon than the multicellular array cycle. The significantly higher level of $\mathrm{CO}_{2}$ apparently produced during the simplified cell cycle (Fig. 5) is a reflection of the lower pH in the later stages of batch growth, i.e. $\mathrm{pH}$ markedly affects the $\mathrm{CO}_{2} / \mathrm{HCO}_{3}{ }^{-}$equilibrium and consequently the $\mathrm{CO}_{2}$ solubility.

\section{Effect of light intensity on growth}

An increase in the incident light intensity increased the growth rate irrespective of the cell cycle expression (Fig. 7). Light saturation, i.e. the light intensity above which any growth rate increase is suppressed, was approached but not reached and in the dark the doubling time approached infinity, i.e. the cells were unable to grow anaerobically in the dark. In Fig. 7, a straight line can be drawn through the points corresponding to $1000 \mathrm{~lx}$ and greater (linear regression coefficient of 0.947) giving a theoretical minimum doubling time of $4.9 \mathrm{~h}$ for the stated cultural conditions. In addition, however, a straight line (linear 

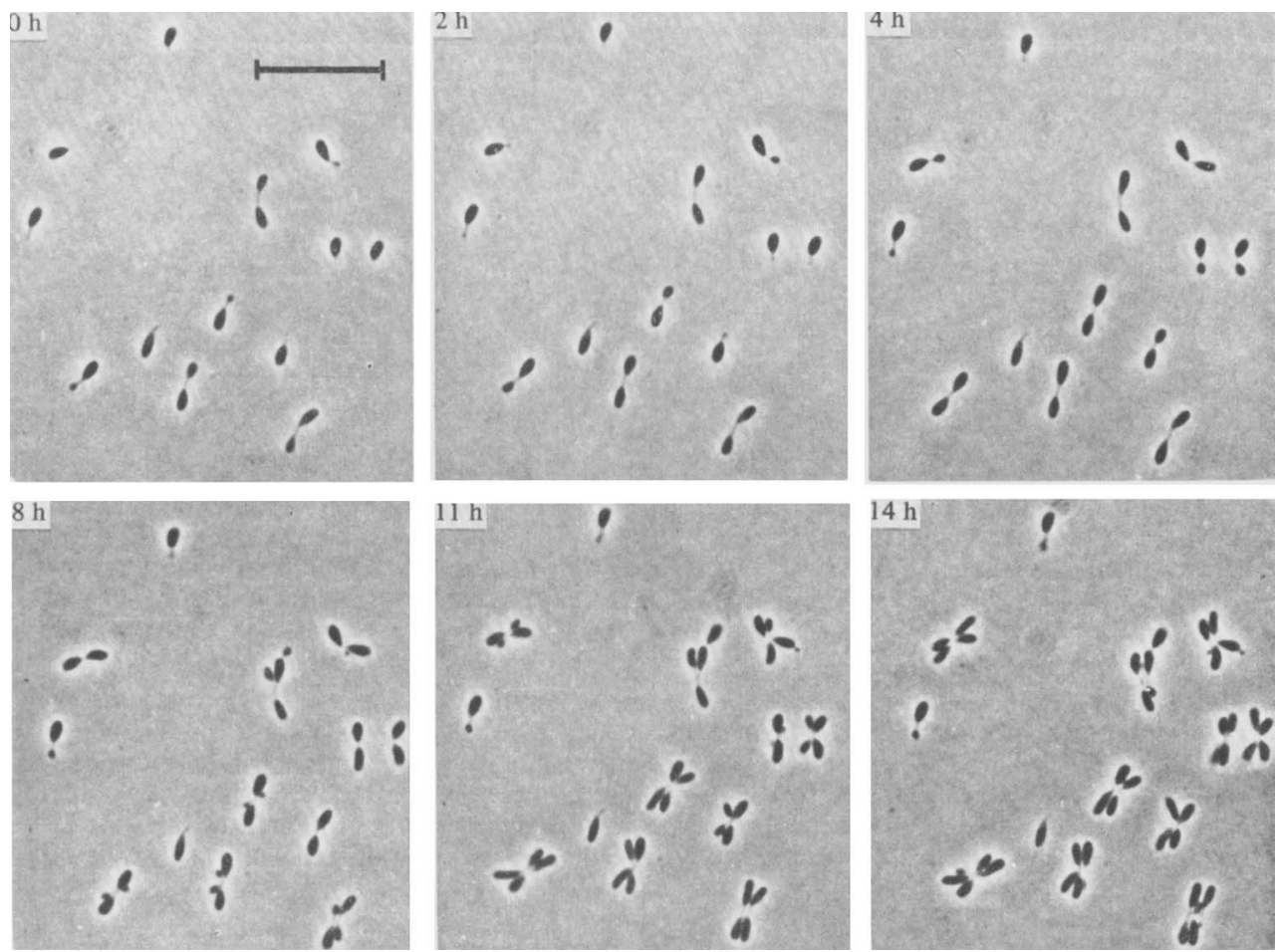

Fig. 3. Sequential phase contrast photomicrographs of a $R$. vannielii slide culture growing photoheterotrophically at $30^{\circ} \mathrm{C}$ with an incident light intensity of $2500 \mathrm{~lx}$. Bar marker represents $10 \mu \mathrm{m}$.

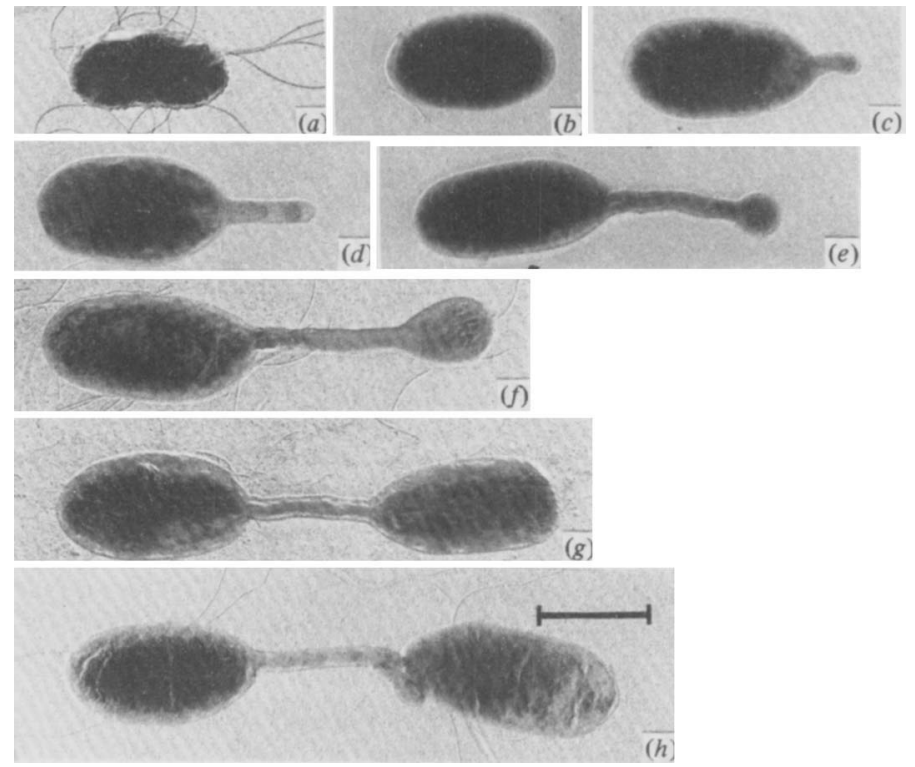

Fig. 4. Electron micrographs (gold/palladium shadowed) depicting morphogenesis and differentiation in $R$. vannielii expressing the simplified cell cycle: $(a)$ peritrichously flagellated swarm cell; $(b$ to $d$ ) swarm cell maturation; ( $e$ to $h$ ) reproductive cycle. Bar marker represents $1 \mu \mathrm{m}$. 


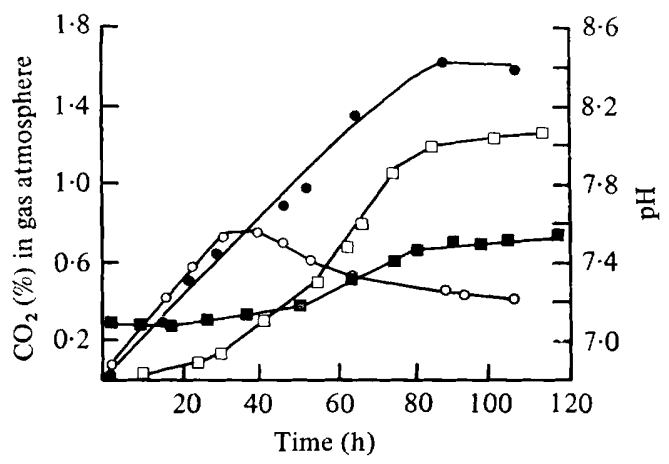

Fig. 5

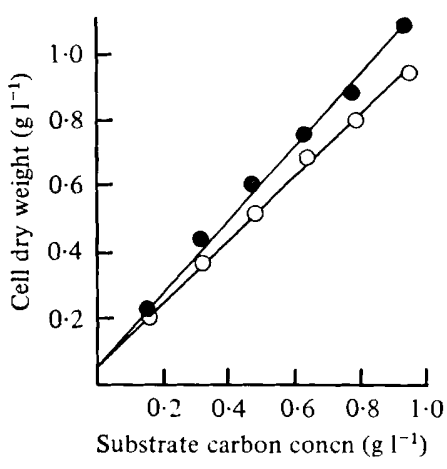

Fig. 6

Fig. 5. pH changes and $\mathrm{CO}_{2}$ production by $R$. vannielii grown photoheterotrophically in batch culture at $30^{\circ} \mathrm{C}$ with an incident light intensity of $2500 \mathrm{~lx}$. pH: simplified cell cycle $(\mathbf{Q})$, multicellular arrays ( $\square$ ). Percentage of $\mathrm{CO}_{2}$ in gas atmosphere: simplified cell cycle $(\odot)$, multicellular arrays (O) $\left[\mathrm{CO}_{2}, \mathrm{O}_{2}\right.$ and $\mathrm{N}_{2}$ tensions were measured in the gas atmosphere within $250 \mathrm{ml}$ flasks by the method of Herbert \& Holding (1972) and the $\mathrm{CO}_{2}$ tension was expressed as a percentage of the total $\mathrm{CO}_{2}$ plus $\mathrm{O}_{2}$ plus $\mathrm{N}_{2}$ ].

Fig. 6. End-point analysis of $R$. vannielii grown on medium containing carbon substrate at different concentrations. Incubation, in $250 \mathrm{ml}$ flasks, was at $30^{\circ} \mathrm{C}$ with an incident light intensity of $1000 \mathrm{~lx}$. On reaching the stationary phase of growth, the dry weight $(50 \mathrm{ml}$ culture), absorbance $(540 \mathrm{~nm})$ and $\mathrm{pH}$ were determined for each flask. Over the range of carbon substrate concentrations tested, cultures were carbon-limited, the amount of growth being directly proportional to the substrate carbon concentration. Plots of absorbance against dry weight were linear. Simplified cell cycle $(\bigcirc)$, multicellular arrays (O).

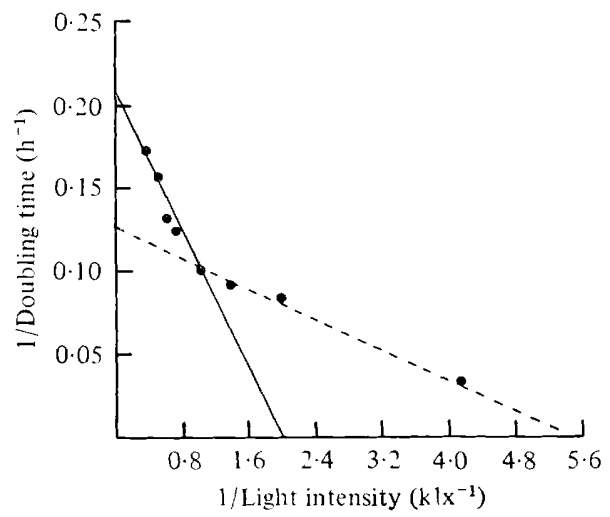

Fig. 7. Double reciprocal plot of doubling time of $R$. vannielii grown at $30^{\circ} \mathrm{C}$ against incident light intensity. Exponential phase cells of $R$. vannielii were resuspended in fresh medium in stoppered glass cuvettes and growth was followed by measuring the absorbance at $540 \mathrm{~nm}$. Different light intensities were obtained by placing the cultures at various distances from a $100 \mathrm{~W}$ tungsten lamp; the maximum incident light intensity tested was $2400 \mathrm{~lx}$.

regression coefficient of 0.988 ) can be drawn through the remaining points indicating that below $1000 \mathrm{~lx}$ the doubling time is limited by a factor other than light.

\section{Derivation of the simplified cell cycle}

Whittenbury \& Dow (1977) have shown that $R$. vannielii swarm cells are formed sequentially from the filament tips of the multicellular arrays, and that the separation process (binary fission) is distinct from plug formation evident in these complexes. It appears, therefore, that the simplified cell cycle is a mechanism for swarm cell production, i.e. constitutive for swarm cell formation, multicelluar complexes being repressed (Fig. 8). 


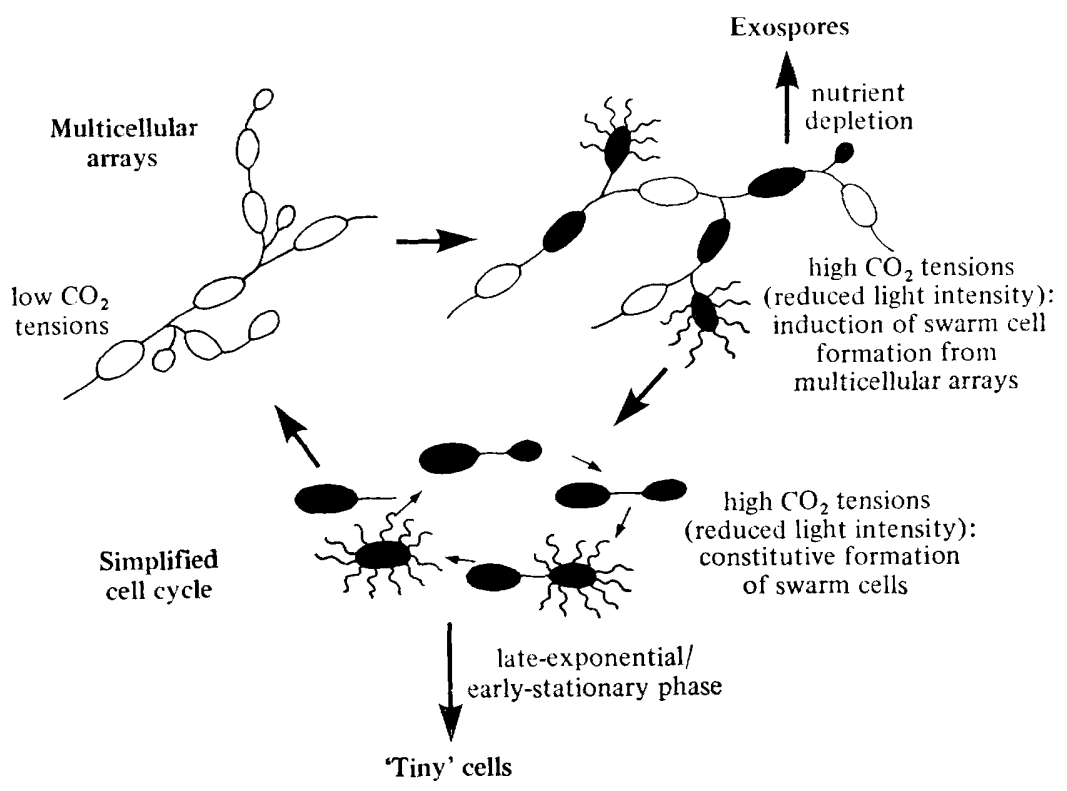

Fig. 8. Diagrammatic representation of the cell cycle expressions of Rhodomicrobium indicating the derivation of the simplified cell cycle.

\section{Control of vegetative cell cycle expression}

On inoculation into fresh medium, an exponential culture of $R$. vannielii (giving expression to multicellular arrays) showed an initial marked decrease in swarm cell production (Fig. 1), the lag phase being characterized almost exclusively by multicellular arrays. From the data available it is most probable that this cessation of swarm cell formation was a consequence of the increased light intensity (decrease in turbidity on inoculation) and the lowered $\mathrm{CO}_{2}$ concentration. As growth proceeded, however, the $\mathrm{CO}_{2}$ concentration increased and the light intensity decreased (due to the increase in culture turbidity). These environmental factors led to the initiation of swarm cell formation which then continued throughout exponential growth. Before the onset of the stationary phase the swarm cell number became constant.

When swarm cells selected from points throughout the batch growth curve were plated on solid media and incubated anaerobically in the light, they gave rise to the smooth colony type, indicative of the simplified cell cycle, only towards the late-exponential/early-stationary phase of growth, i.e. at a point coincident with the onset of low light intensity (high culture turbidity) and high $\mathrm{CO}_{2}$ concentration. This colony type constituted between 1 and $2 \%$ of the total population.

When grown in continuous culture under high $\mathrm{CO}_{2}$ tensions $(\mathrm{pH}$ controlled by the addition of gaseous $\mathrm{CO}_{2}$ ), R. vannielii gave expression exclusively to the simplified cell cycle. However, on reduction of the $\mathrm{CO}_{2}$ tension ( $\mathrm{pH}$ controlled by the addition of $0 \cdot 1 \mathrm{M}-\mathrm{HCl}$ ) expression of the simplified cell cycle was repressed and the culture reverted to one composed of multicellular arrays (unpublished result). In this series of experiments the factor most influential on vegetative cell cycle expression was the $\mathrm{CO}_{2}$ tension.

Cells expressing the simplified cell cycle could be maintained in this form indefinitely provided the culture was re-inoculated into fresh medium during the mid-exponential phase of growth. However, subculturing cells expressing the simplified cell cycle into conditions conducive to expression of multicellular arrays (low $\mathrm{CO}_{2}$, high light intensity) did not give immediate reversion of the cell cycle expressed; this took a further two to three subcultures and was most rapid when inoculation was from stationary phase cultures. 


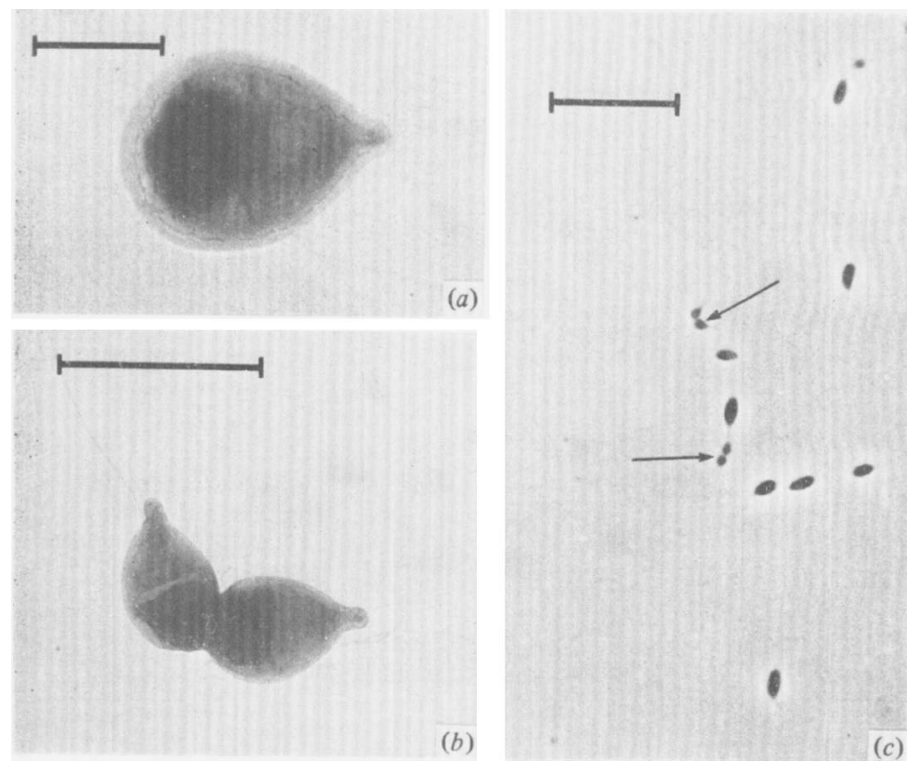

Fig. 9. Micrographs of the 'tiny' cells produced by $R$. vannielii, expressing the simplified cell cycle, on entering the late-exponential/early-stationary phase of growth: $(a, b)$ gold/palladium shadowed electron micrographs; $(c)$ phase contrast photomicrograph ("tiny' cells are arrowed). Bar markers represent $0.5 \mu \mathrm{m}$ in $(a), 1 \mu \mathrm{m}$ in $(b)$ and $10 \mu \mathrm{m}$ in $(c)$.

The failure to obtain reversion of expression immediately on alteration of the environmental conditions pointed to the possibility that the simplified cell cycle was a consequence of mutation. However, the frequency with which the cells giving expression to the simplified cell cycle arose, the reversion rate, and the correlation of the expression of the simplified cell cycle with the $\mathrm{CO}_{2}$ tension indicate that this was not the case.

The role of $\mathrm{CO}_{2}$ tension and light intensity in the modification of cell cycle expression in R. vannielii remains unclear. However, the involvement of $\mathrm{CO}_{2}$ as a probable trigger for cellular differentiation in other organisms has been widely implicated (Lones \& Peacock, 1960; Bartnicki-Garcia \& Nickerson, 1962; Roberts, 1964; Elmer \& Nickerson, 1970).

Rhodomicrobium vannielii presents a unique model system in which an obligate differentiation sequence, environmentally induced modification of vegetative cell cycle expression, and formation of a resting cell (exospores) are integrated. The importance of the switch in vegetative cell cycle expression lies in its potential to help elucidate the mechanism(s) of environmentally induced changes in cellular expression.

\section{'Tiny' cells}

When grown as the simplified cell cycle, $R$. vannielii did not form exospores. However, on reaching the late-exponential/early-stationary phase of growth such cultures contained cells of unusual but characteristic phenotype in large numbers (Fig. 9). These cells were not resistant to adverse environmental stress and their physiological capabilities have yet to be determined. They did not appear in cultures growing as multicellular arrays; they were unique to the simplified cell cycle.

\section{REFERENCES}

Bartnicki-Garcia, S. \& Nickerson, W. J. (1962). Induction of yeast-like development in Mucor by carbon dioxide. Journal of Bacteriology 84, 829-840.

CoNTI, S. F. \& Hirsch, P. (1965). Biology of budding bacteria. III. Fine structure of Rhodo-

microbium and Hyphomicrobium spp. Journal of Bacteriology 89, 503-512.

Douglas, H. C. \& Wolfe, R. S. (1959). Motility of Rhodomicrobium vannielii. Journal of Bacteriology 78, 597-598. 
Dow, C. S., Westmacott, D. \& Whittenbury, R. (1976). Ultrastructure of budding and prosthecate bacteria. In Microbial Ultrastructure, pp. 187-221. Edited by R. Fuller \& D. W. Lovelock. London \& New York: Academic Press.

Duchow, E. \& Douglas, H. C. (1949). Rhodomicrobium vannielii, a new photoheterotrophic bacterium. Journal of Bacteriology 58, 409-416.

Elmer, G. W. \& Nickerson, W. J. (1970). Nutritional requirements for growth and yeast like development of Mucor rouxii under carbon dioxide. Journal of Bacteriology 101, 595-602.

Gorlenko, V. M. (1969). Spore formation in a budding photoheterotrophic bacterium. Microbiology (English translation) 38, 106-111.

Harder, W. \& AtTwood, M. (1978). The biology, physiology and biochemistry of hyphomicrobia. Advances in Microbial Physiology 17, 1-56.

Herbert, R. A. \& Holding, A. J. (1972). Rapid separation and estimation of gases produced or utilized by micro-organisms. Journal of Chromatographic Science 10, 174-175.

Hirsch, P. (1974). Budding bacteria. Annual Review of Microbiology 28, 392-44.4.

LEIFSON, E. (1964). Hyphomicrobium neptunium sp.n. Antonie van Leeuwenhoek 30, 249-256.

Lones, G. W. \& Peacock, C. L. (1960). Role of carbon dioxide in the dimorphism of Coccidioides immitis. Journal of Bacteriology 79, 308-309.
Murray, R. G. E. \& Douglas, H. C. (1950). The reproductive mechanism of Rhodomicrobium vannielii and the accompanying nuclear changes. Journal of Bacteriology 59, 157-167.

Phillips, D. H. \& Johnson, M. J. (1961). Measurement of dissolved oxygen in fermentation. Journal of Biochemical and Microbiological Technology and Engineering 3, 261-275.

ROBERTS, D. S. (1964). Synergistic effects of salts and carbon dioxide on Dermatophilus dermatonomus. Journal of General Microbiology 37, 403-410.

Ryter, A. \& Kellenberger, E. (1958). Étude au microscope électronique de plasmas contenant de l'acide désoxyribonucléique. I. Les nucléotides des bactéries en croissance active. Zeitschrift für Naturforschung 13b, 597-605.

Staley, J. T. (1968). Prosthecomicrobium and Ancalomicrobium: new prosthecate freshwater bacteria. Journal of Bacteriology 95, 1921-1942.

Whittenbury, R. \& Dow, C. S. (1977). Morphogenesis and differentiation in Rhodomicrobium vannielii and other budding and prosthecate bacteria. Bacteriological Reviews 41, 754-808.

Whitienbury, R. \& McLeE, A. G. (1967). Rhodopseudomonas palustris and $R$. viridis-photosynthetic budding bacteria. Archiv für Mikrobiologie 59, 324-334. 